\title{
Beliefs and practices in diabetes care
}

\section{Creencias y prácticas en el cuidado de la diabetes}

\author{
Juan Pablo Álvarez-Najar ${ }^{1}$ (D), Mery Luz Valderrama-Sanabria² ${ }^{\text {(D) }}$, Amalia Priscila Peña-Pita ${ }^{3}$ \\ 1. Universidad Pedagógica y Tecnológica de Colombia. Tunja, Colombia. E-mail: juanpablo.alvareznajar@gmail.com - http://orcid.org/0000-0002-0875- \\ 9244 \\ 2. Universidad de los Llanos. Villavicencio, Colombia. E-mail: mvalderrama@unillanos.edu.co - http://orcid.org/0000-0003-1618 \\ 3. Universidad de los Llanos. Villavicencio, Colombia. E-mail: priscila.p@unillanos.edu.co - http://orcid.org/0000-0003-1947-3812 \\ Typology: Review article \\ To cite this article: Álvarez-Najar JP, Valderrama-Sanabria ML, Peña-Pita AP. Beliefs and practices in diabetes care. Duazary. 2020 enero; 17(1): 74 - 86. Doi: \\ http://dx.doi.org/10.21676/2389783X.3218 \\ Received on May 09 of 2018 \\ Accepted on May 17of 2019 \\ Published online on November 19 of 2019
}

\begin{abstract}
Keywords:

Culture;

diabetes

mellitus;

quality of life;

Lifestyle;

knowledge.

Diabetes mellitus is considered a chronic non-communicable disease with high morbidity. It its highly prevalent and entails high social, family, and economic costs. Interventions aimed at lifestyle changes are fundamental in managing diabetes; therefore, patients should be educated. The aim of the study is to identify the beliefs and practices of patients with diabetes mellitus and propose nurse care according to these precepts. This is a descriptive study of systematic literature review. Articles published in Spanish, English, and Portuguese between 2001-2018 were searched in databases such as Springer Science, Elsevier, ProQuest, Science Direct, Index, Pubmed, SciELO, Medigraphic, and Medline during 2016- 2018, A total of 49 studies contributed to fulfilling the objective. Beliefs about the management of disease include the use of herbs and "fright" as a cause. Others take into account risk factors such as heredity, obesity, poor eating habits. There are various beliefs in relation to insulin treatment. Spirituality is emphasized since some patients take refuge in God and prayer. It is important to understand the person, from their values, beliefs, customs and feelings. Education is a fundamental tool to control the disease, but health beliefs must be taken into account in order to achieve favourable results.
\end{abstract}

\section{RESUMEN}

Palabras clave: cultura; diabetes mellitus; calidad de vida; estilo de vida; conocimiento. presenta alta prevalencia, costo social, familiar y económico. Las intervenciones orientadas hacia el cambio del estilo de vida son fundamentales para su manejo, por eso los pacientes deben recibir educación. El objetivo fue identificar las creencias y prácticas de las personas que presentan diabetes mellitus, para proponer el cuidado de enfermería acorde con estos preceptos. Estudio descriptivo de revisión sistemática de la literatura, búsqueda de artículos publicados entre el 2001 a 2018, en español, inglés y portugués en bases de datos (Springer Science, Elsevier, ProQuest, Science Direct, Index, Pubmed, SciELO, Medigraphic y Medline) durante los años 2016 a 2018. Se tomaron 49 estudios que aportaron al cumplimiento del objetivo. Dentro de las creencias para el manejo de la enfermedad, se encuentra el uso de hierbas; algunos consideran como causa "susto" o "espanto" y otros factores de riesgo como la herencia, la obesidad y los malos hábitos de alimentación. Frente al tratamiento con insulina se presentan diversas creencias. Se resalta la espiritualidad, en la que se busca refugio en Dios y la oración. Es importante entender a la persona desde sus valores, creencias, costumbres y sentimientos. La educación es una herramienta fundamental para controlar la enfermedad. 


\section{INTRODUCTION}

From nursing, it is timely to consider that, a diabetic patient' values, beliefs and customs should be kept in mind in adjusting their health care so that each orientation is directed to the cultural setting where the person lives, and the nurse takes on the challenge of understanding cultural patterns and influences ${ }^{1}$. At present, people's lifestyles have changed because of globalization, new technologies, scientific advances, climatic diversity and modern economic models. In this way, unhealthy habits such as alcohol consumption, smoking, energy drinks, sedentariness and an unsuitable diet are causing more and more frequently chronic diseases like diabetes ${ }^{2}$.

Globally, the prevalence of diabetes keeps growing ${ }^{3-}$ 5; more than 382 million individuals in the world suffer from this disease today and this number is expected to increases to 592 million by $2035^{6-9}$, being higher in developing countries like Colombia ${ }^{10-}$ 11 .

Diabetes mellitus is a chronic disease with multiples causes that appears when the body cannot produce or effectively use insulin, a hormone produced by the pancreas that permits food glucose to get into the body cells, where it is transformed into the energy necessary for muscles and tissues to work. So, a person with diabetes does not absorb glucose adequately and it keeps traveling in the blood. This is known as hyperglycaemia and affects body tissues over time ${ }^{12}$. On its initial stage, it does not exhibit symptoms and, when detected belatedly and not treated appropriately, it causes seriously health complications such as myocardium acute stroke, blindness, kidney failure, lower extremities amputation and even death ${ }^{13-16}$.

Studies mention that people's unhealthy habits increases the prevalence of obesity and overweight, a risk factor for this disease ${ }^{13,14,17}$. Also, it is true that the treatment of diabetes is complex and the outcome depends largely on the understanding, skill and motivation, whit ones the person confronts the new reality. Therefore, the education provided to both the patient and their family, as well as their cultural diversity, is fundamental to the success of the treatment and their life conditions ${ }^{18-20}$.
Lopez and Avalos ${ }^{21}$ state that diabetes is a product of a series of factors that interact with the emotional state and is present in many cultures. If it is possible to share knowledge of the disease with the person and their family and promote selfcare actions ${ }^{22,23}$. So, understanding and recognition, together with treatment, become indispensable factors that can improve the quality of life and care of these patients ${ }^{24,25}$.

It is clear that effective care in the management of these patients reduces disease complications; therefore, emphasis should be place on diet, physical activity, foot care and other situations that may lead to suffer largest difficult. However, this care should be provided on case-by-case basis in accordance with the patient's culture and beliefs to accomplish better results ${ }^{26,27}$.

Literature shows the problems that appear of provides competent care and appropriate to the cultures, because of the cultural diversity; on occasion, the professional nurses refer doubts regarding the compression of the belief and health practice of the communities ${ }^{28-30}$.

The aim of the study is to identify the beliefs and practices of patients with diabetes mellitus and propose nurse care in accordance with these precepts.

\section{MATERIALS AND METHODS}

\section{Design and Settings}

This is a descriptive study of a systemic literature review. To select the publications that broach beliefs and customs of people with diabetes mellitus, different databases were searched, such as Springer, Science, Elsevier, ProQuest, Science Direct, Pubmed, SciELO, Medigraphic and Medline, between June 2016 and March 2018.

\section{Procedure}

The information research was developed by specificity, restricting it to Mesh terms (Medical Subject Headings) and Decs (Descriptors in Health sciences), and by sensitivity using the search engine Google Scholar.

The terms "culture," "diabetes mellitus," "quality of life," "lifestyle," "knowledge," "attitudes" and 
"health practices" were identified. Zotero, a reference manager, was used to eliminate duplicated articles.

The descriptors were used and combined with the operator "and", conditioning its presentation in the title of the work, to perfect the relevant studies to the selected theme.

\section{Data Collection}

To obtain the sample, the inclusion criteria adopted were, research works and publications in the form of articles, in full text, about examined diabetes mellitus, published between 2001- 2018, and written in Spanish, English and Portuguese.

Five hundred and thirty-eight potential studies were identified, which were organized and filed in folders with the name of the database where they were found. Four hundred and eighty-nine studies were excluded, of which 347 did not address the required theme, 97 were not available in full text and 45 did not belong to the period selected. Once the methodological quality was assessed, 49 research papers met the requirements to accomplish the objective. Figure 1 shows the systematic review process that was realized to carry through the research.

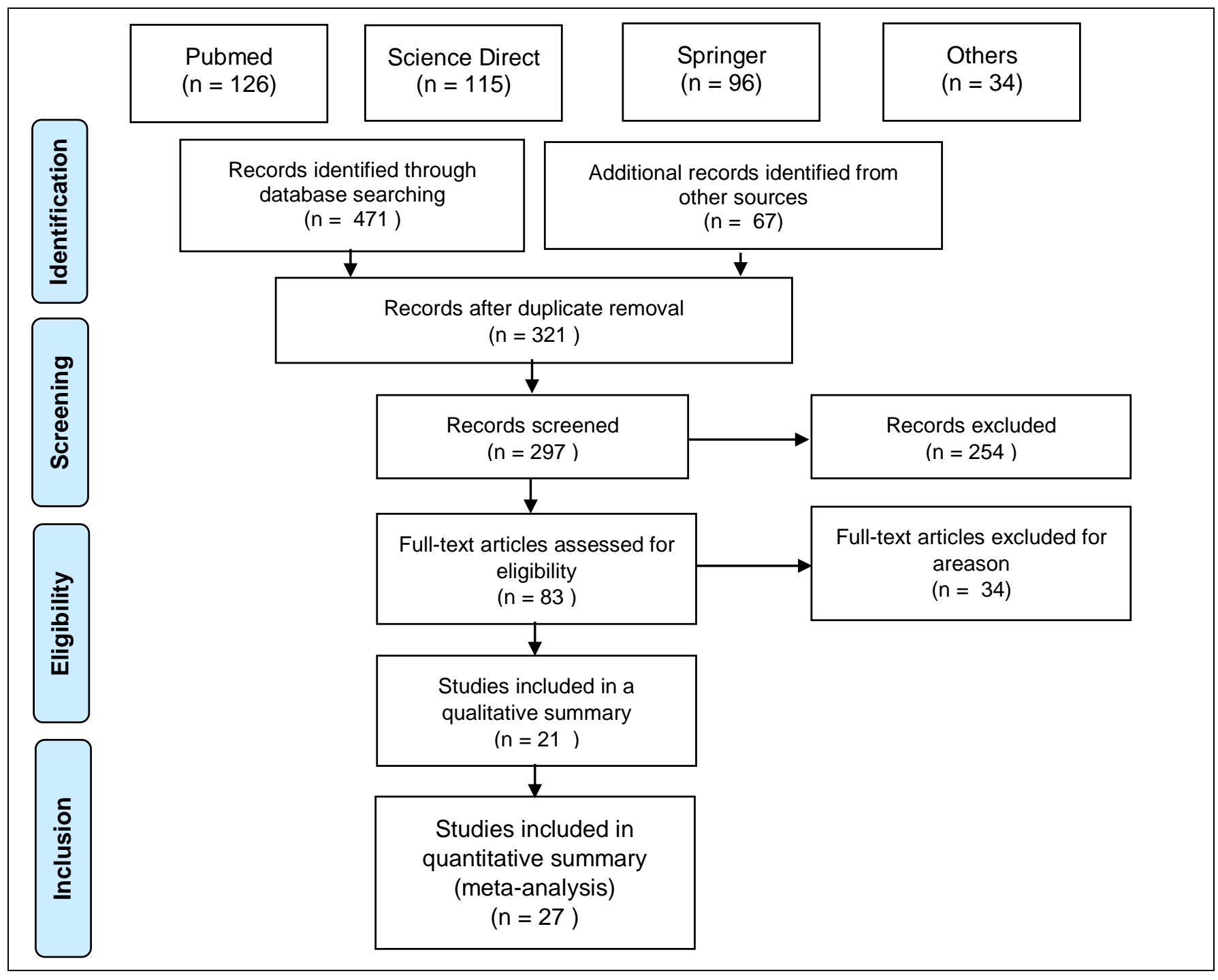

Figure 1. Flow chart of information through the different phases of a systematic review. 


\section{Ethical Considerations}

The research was considered of minimum risk; given that it did not involve human beings.

\section{RESULTS AND DISCUSSION}

The concept of beliefs has been defined from different areas, such as transcultural nursing, psychology and sociology, as a representation that intends to integrate both the individual and society. Also, it reflects a holistic approach to health care that includes physical, social and spiritual dimensions with a standpoint to the health promotion and prevention of the illness ${ }^{27}$.

Moreover, the concept of care practice refers to a behaviour that seeks the subject wellbeing, an expression of the human will, that aims to take care of health ${ }^{26}$. However, care beliefs and health practices are expressions of the care culture of social groups. In this regard, Madeleine Leininger defines Transcultural Nursing as a "discipline of study and practice focus in the comparation of the differences and similarities of the cares, in a same culture or in different cultures, with the purpose of pay attention to the human beings for they can reach and maintain the health based on their culture"27.

Being familiar with cultural diversity is fundamental to health practices ${ }^{28}$. Therefore, the values and beliefs with which a person is raised and is going form himself are important, because they determine the individual's way of acting and preferences. In this way, nurses should keep their mind open, respect the difference as to patients' values and beliefs, and offer appropriate care from a scientific and cultural point of view ${ }^{29-33}$.

Accordingly, if a person with diabetes mellitus is carry on good practices to his health, will be accepted his beliefs, but if on the contrary they affect his health, should be entered to analyse what is happening with the possibility of resize the cares.

The nurse should be a mediator between emic care and professional care to avoid to unleash in insistences of professional type, what is intended is to favour the decision making in the family environment, recognizing the particular life experiences, the changes and activities of the daily life that will be good like orientation to facilitate the care and the illness adaptation. So, the patient expects that the nurse will respect their values, beliefs, ways of life and necessities.

As for the systematic review conducted, the distribution of scientific production on beliefs and practices regarding diabetes is presented in Tables 1 and 2, according to year of publication and language.

Table 1. Distribution of scientific production on beliefs and practices regarding diabetes, according to year of publication.

\begin{tabular}{|c|c|c|c|c|c|c|c|c|c|c|c|c|c|c|}
\hline Year & 2001 & 2006 & 2007 & 2008 & 2009 & 2010 & 2011 & 2012 & 2013 & 2014 & 2015 & 2016 & 2017 & 2018 \\
\hline $\begin{array}{c}\text { Number of } \\
\text { articles }\end{array}$ & 1 & 1 & 1 & 1 & 1 & 2 & 9 & 4 & 8 & 6 & 5 & 4 & 4 & 2 \\
\hline TOTAL & \multicolumn{14}{|c|}{1} \\
\hline
\end{tabular}

Table 2. Distribution of scientific production on beliefs and practices regarding diabetes, according to language of publication.

\begin{tabular}{|c|c|}
\hline Year & Number of Articles \\
\hline English & 19 \\
\hline Portuguese & 1 \\
\hline Spanish & 29 \\
\hline Total & 49 \\
\hline
\end{tabular}


Beliefs and practices identified in the systematic literature review are introduced below.

\section{Beliefs and practices on the cause of the disease}

Some individuals have attributed diabetes mellitus to "fright" or "terror"; others have in mind risk factors such as inheritance, obesity and bad eating habits $^{33}$. At the same time, there are patients that see the disease as God's punishment for something they did in the past, thus becoming sort of a test of faith. So they receive it and accept it as part of God's plan, but there find consolation in that God will help them to endure the disease ${ }^{34-36}$.

However, other persons have attributed diabetes to alcohol ingestion, little exercise and excess sugary food.

\section{Beliefs and practices on the management of the disease}

There are natural products of plant origin used for treating diabetes, including more than 800 plants that have hypoglycaemia characteristics. Some herbs have shown to relieve diabetes symptoms and help to prevent complications; for example, papaya skin reduces glucose and fat on blood, and lemon with water ${ }^{35-37}$.

Although people believe in treatments in the form of tea, infusions or extracts, they also follow medical prescriptions since medicinal plants reduce the level of glucose in blood but not as much as insulin and other medicines ${ }^{35-38}$.

Some plants employed are anamú, whose leaves are cooked and drank as tea; yancón, a tuber ingested as infusion, but also available in capsules and as tea, and the insulin in leaf is drank in infusion; moringa leaves are added to food or drank in aromatic water. Ahuyama leaves are also used, which are the cooked to be drank later in cold water. As to fruit, is strawberry in juice, kiwi eaten grated daily, and citron in infusion with black cow bile recently extracted from the animal stand out.

Others beliefs are cooking a cow hoof or a cow paw cooked and drinking this water by nine days, cooking green beans and drinking this water, drinking oregano leaf infusion, and eating aloe vera liquefied pulp. Those drinks are ingested two or three times a day. Another practice identified is to keep three seeds of a tree whose name is unknown tied and close to the body ${ }^{39}$.

In relation to feet and stump care, literature mentions the importance of keeping the feet dry and clean, when they do not have wounds, assure that they use lotion and talc, while patients that have presented ulceration, use Clorox as disinfectant, as the bath with knowledge of herbs like yanten, paico, domeboro and the seeds of seven avocados $^{40-42}$.

The previous practices have been passed on from generation to generation, or followed by influence of neighbours, friends or other patients that know them and care themselves ${ }^{42}$.

Regarding the beginning of the treatment with insulin, some patients consider it a failure and punishment for not having taken care of themselves on time and the daily injection produces horror and pain in them. they also feel it causes drug dependence, and the saddest thing, that it will worsen the disease ${ }^{19}$.

Likewise, some individuals have the idea that insulin cause blindness and therefore are afraid of using $i^{38,44}$. The patient's family mentions that they fear when the doctor prescribes insulin because it causes weight gain and worsens their health state. Additionally, to control the glycaemia, many punctures are required a day, which generates feelings of anguish and temperament changes, that is why usually the user abandons the treatment. However, other persons see insulin as the medication that heals them ${ }^{45-47}$.

Regarding the use of the other medicaments, it was found that patients feel improvement with the tablet-based treatment, even if they thought that in the long term it will cause them some type of damage, especially to the kidney because of the quantity of medicine ingested. For this reason, they resort to other alternatives from traditional medicine such as infusions and medicinal plants ${ }^{34,44,46}$. In addition, the belief that diabetes is curable may have a negative effect because doctors run the risk that patients abandon the treatment once the disease is under control ${ }^{48}$. 
At the same time, some persons recognise that the key to the treatment lies in a healthy diet, but sometimes they do not have the money to consume the food indicated by the nutritionist such as vegetables, fruits, milk, cheese and beef. In addition, pharmacologic treatments, laboratory exams and appointments with different specialists are not provided in a timely manner and this causes additional costs to the patient and their family $y^{44,47,49}$. Many patients express that they have abandoned the treatment because health workers confuse them when giving them indications for disease management: the doctors prescribe one thing, the nutritionists others, and they do not know who to believe. They also feel insulted by prohibition and the imposition of new lifestyles ${ }^{34,37}$.

\section{Beliefs and practices on the diabetic foot}

One of diabetes complications is neuropathy, the most common factor in originating ulcers on the feet and is present in $60 \%$ of the persons over 60 . If this anomaly is not treated adequately, it can progress to an amputation of a lower limb ${ }^{50}$. In these patients, depression is usual; many people fear that the infection reappears. In addition, behind an amputation, the lifestyle of the person changes because they need other types of shoes or prosthesis and they feel embarrassed because the infection is visible and sometimes smells ${ }^{51,52}$. The problems of the feet need another type of attention and, thus, basic care must be part of the routine. However, in occasions, nurses are not aware of this; in addition are scant health workers that realize measure of prevention of the diabetic neuropathy, do not even examine the feet of the persons ${ }^{52-57}$.

Using nail clippers or sharp elements is not recommended because it favours wounds and ulcers. It is advisable to use water bags under the stump of the lower limb as a measure of support to prevent pressure in the area. The use of talc is discouraged too because it produces dry skin ${ }^{50}$.

As for the causes of diabetic foot it was found that the majority attribute it to being hit on the feet, walking barefoot, cutting the nails incorrectly, poke it with a nail, or not taking care of themselves properly. However, the knowledge of the risk factors for the diabetic neuropathy is limited, which impedes the suitable prevention of diabetic foot because it does not reach to assume healthily conducts for the health protection ${ }^{55}$.

With respect to the prevention of diabetic foot, the Mexican literature reports that the patient check himself to confirm if any injury has appeared and later goes to the podiatrist or a health institution where necessary. To prevent the apparition of diabetic foot, it is necessary to protect the feet from traumatisms, to not walk barefooted, dry the interdigital spaces and have nails cut by a feet care specialist. However, there are persons that prefer to take care of this at home by themselves or helped by a relative ${ }^{55-57}$. Patients do not walk barefooted and not even use flip-flops to prevent punctures, injuries and hits, but some prefer sandals because they are more comfortable.

It is important to tell the patient that they must inspect shoes before use them, wear cotton socks, not to use chemical substances nor elastic bands, control the temperature of the bathwater, not to use new shoes for a long period to prevent injuries ${ }^{55-}$ 58.

As regards to the apparition of diabetic foot, some persons go to the doctor for treatment, others prefer the treatment inside the house, with rest and warm water baths with calendula to decrease the injury and there patients that consult directly with the podiatrist ${ }^{54}$.

Local use and intake of calendula prevent pain and inflammation after amputation; piper aduncum and hierbamora infusions are also useful because they prevent infections and is indicated to treat ulcers in diabetic foot ${ }^{56}$.

Family support is necessary before, during and after the amputation; literature shows that it is an important factor as an expression of fondness, love and help from the caregiver to who experiments the change on their body and influences the lifestyle, image and adopted practices ${ }^{53,57}$.

Health workers play a fundamental role in promoting selfcare practices, one of which is the prevention of diabetic foot, which requires simple actions directed to the person, their family and community ${ }^{57,59-61}$. 


\section{Beliefs and practices related to spirituality}

The disease experience poses questions about the meaning of life, suffering and death; this is why many people take refuge in $\operatorname{God}^{19,20,33}$. The patient lives their spirituality in some religious belief as a source of support to face a hard situation, which can turn it into a protective factor that favours their dealing with the disease $\mathrm{e}^{20,62}$. The patient has no other choice but to resort to God and their religious beliefs, so they carry pictures of the virgins and saints to whom they pray to be healed ${ }^{53}$. Attendance to temples and praying gives patients peace, relief and serenity ${ }^{55}$; believing in a superior being provides them physical health or spirituality by means of forgiveness and purification to face the disease ${ }^{56-62}$.

The diabetic person can take shelter in their spirituality to find strength and endure the illness. The confrontation strategies that are outlined are prayer, meditation, finding themselves and reading spiritual texts to deal with chronic diseases. Likewise, spiritual beliefs have helps them to face limitations and sufferings when they cling onto a superior being like God ${ }^{63-66}$.

Supported on the previous practices, religious beliefs make possible the condition change between feeling very bad to preserve the faith in the improvement, waiting to the God will, but at the same time expressing a gratitude feeling for preserve the life. Literature reports that persons with diabetes entrust their health condition to "Most Holy", "Saint Marta", "The Lord of Miracles", "God" and "Most Holy Maria". Also, they cling to pictures of Our Lady of Mount Carmel and crucifixes $^{39,66,67}$.

\section{Particular beliefs}

Certain behaviours sometimes do not contribute to improving the diabetic patient's quality of life of the ; there are users who do not believe in the benefits of physical activity and a balanced diet and medication to control the disease and lead an almost normal life; therefore, those irrational beliefs impede the control and management of the disease ${ }^{68}$. Another particular practice is the use of Lucilia sericata or green fly larvae in diabetic foot injuries because they eat the infected part of the foot ${ }^{40}$.

\section{Selfcare beliefs and practices}

Selfcare is an action that at present is difficult to incorporate, given the influences from the external environment, as well as the unwillingness of the persons that suffer a chronic disease. Studies report that some practices apparently simple such as decreasing the consumption of sugar in the diet, avoiding fat or working out are not followed by the general population ${ }^{68,69}$.

Promoting selfcare is a fundamental task of nurses; however, to carry it out, they must consider particular aspects of patients, such as their sociodemographic characteristics and culture, in order to have a guide or a starting point to take appropriate care actions.

Consequently, taking care of a person implies the recognition of their cultural values, beliefs and convictions, even more when the diabetes treatment is complex, and the outcome depends largely on understanding, skill, motivation and family support, hence the relevance of learning to take care of themselves ${ }^{68,70}$. If the person and their family know all the information about the disease and how to take care of themselves, they will be able to follow medical indications and keep glycaemia values within a normal range ${ }^{71}$.

\section{CONCLUSION}

Nurses are able to provide individualized and quality care to the person with diabetes, who may come from diverse cultures. A person with diabetes experiments physical, psychological and emotional changes, which affect their quality of life; therefore, it is important to understand it in its peak, respecting their values, beliefs, practices and feelings.

This research allowed to make professional development visible by recognising the cultural communication that guides care to sceneries proper to the human being.

From a teaching perspective, it favours the promotion of care congruent with the diabetic patient's culture and shows the urgent need to train the student in providing cultural-oriented care, because in the professional practice some nurses 
have had cultural conflicts for not having received this type of education.

From the research area, is look for to use the discoveries of the cultural care in the patient with diabetes so that the person achieves to confront the illness.

\section{CONFLICTS OF INTEREST STATEMENT}

The authors declare that they have no conflict of interest whatsoever.

\section{AUTHORS' CONTRIBUTIONS}

First Author: Reviewed literature, developed the theoretical framework, selected the research design, built the database, prepared figures, analysed results and translated the article into English.

Second Author: Reviewed literature, built the database, analysed results, adjusted the article structure to journal regulations, revised od style and wording, drew conclusions and sent the article to the journal.

Third Author: Reviewed literature, analysed results, drew conclusions and listed references.

\section{BIBLIOGRAPHIC REFERENCES}

1. Moreno ME, Muñoz L. De la Teoría de la Enfermería a la Práctica: Experiencias con proyectos de gestión del cuidado. Chía, Universidad de la Sabana; 2016.

2. Observatorio de Diabetes en Colombia. Diabetes en Colombia, descripción de la epidemiologia actual [Internet]. Bogotá: ODC. [cited 2017 Mar 3]. Available at: https://odc.org.co/files/Diabetes_en_Colombia _descripcion_de_la_epidemiologia_actual.pdf

3. Andreassen LM, Sandberg S, Kristensen GB, Sølvik $\varnothing$, Kjome RL. Nursing home patients with diabetes: Prevalence, drug treatment and glycemic control. Diabetes Research and clinical practice. 2014 Jul;105(1):102-109. Doi: 10.1016/j.diabres.2014.04.012

4. Gucciardi E, Wing-Sheung V, Manuel L, Sidani S. A systematic literature review of diabetes selfmanagement education features to improve diabetes education in women of Black African/Caribbean and Hispanic/Latin American ethnicity. Patient Education and Counseling. 2013 Aug; 92(2):235-245. Doi: 10.1016/j.pec.2013.03.007 https://www.sciencedirect.com/science/article /pii/S073839911300116X

5. Modic MB, Vanderbilt A, Siedlecki SL, Sauvey R, Kaser $N$, Yager $C$. Diabetes management unawareness: what do bedside nurses know? Applied Nursing Research. 2014 Aug;27(3):157161. Available at: https://scihub.tw/10.1016/j.apnr.2013.12.003

6. Hoyos-Duque TN, Arteaga-Henao MV, MuñozCardona M. Nonadherence factors to treatment of people with type 2 Diabetes Mellitus at home. Family caregiver's view. Invest Educ Enferm [Internet]. 2011 [cited 2017 Aug 20];29(2):194203. Available at: http://www.scielo.org.co/pdf/iee/v29n2/v29n2 a04.pdf

7. Pimentel-Jaimes JA, Sanhueza-Alvarado $O$, Gutiérrez-Valverde JM, Gallegos-Cabriales EC. Evaluación del efecto a largo plazo de intervenciones educativas para el autocuidado de la diabetes. Ciencia y Enfermería [Internet]. 2014 [cited 2017 Nov 20];20(3):59-68. Doi: http://dx.doi.org/10.4067/S071795532014000300006.

8. Gómez-Aguilar PIS, Avila-Sansores GM, CandilaCelis JA. Estilo de vida y control metabólico en personas con diabetes tipo 2, Yucatán, México. Enferm Inst Mex Seguro Soc [Internet]. 2012 [cited 2017 Sep 20];20(3):123-129. Available at: http://revistaenfermeria.imss.gob.mx/editorial /index.php/revista_enfermeria/article/view/34 $1 / 393$

9. Agema $P$, Sherifali D. Determining the Impact of an Intervention to Increase Problem-Solving Skills in Diabetes Self-Management: The Diabetes Problem-Solving Passport Pilot Study. Canadian Journal of Diabetes. 2012 Aug;36(4):199-203. Doi: https://doi.org/10.1016/j.jcjd.2012.07.004 
10. Ünsal-Avdal E, Arkan B. Individual and Group Education in Diabetes and Outcomes. Aquichan. 2014 Jun;14(2):138-147. Doi: 10.5294/aqui.2014.14.2.1

11. Aráuz AG, Sánchez G, Padilla G, Fernández M, Roselló M, Guzmán S. Intervención educativa comunitaria sobre la diabetes en el ámbito de la atención primaria. Panam Salud Pública [Internet]. 2001 [cited 2017 Jul 10];9(3):145$153 . \quad$ Available at: https://www.scielosp.org/pdf/rpsp/2001.v9n3/ 145-153/es

12. Federación Internacional de la Diabetes. Atlas de la Diabetes. Brussels-Belgium: FID; 2016 Available at: https://www.fundaciondiabetes.org/upload/pu blicaciones_ficheros/95/IDF_Atlas_2015_SP_W EB_oct2016.pdf

13. Hernández-Ávila $M$, Gutiérrez JP, Reynoso Noverón N. Diabetes mellitus en México. El estado de la epidemia. Salud Pública de México [Internet]. 2013 [citado 2017 Abr 10];55(2):129136. Available at: https://www.scielosp.org/article/spm/2013.v5 5suppl2/s129-s136/es/

14. Barría-von B F, Harnisch K, Montes N, Pio G, Barría-M F. Analysis of diabetic patients controlled at primary level in Concepcion Health Service. Rev chil endocrinol diabetes [Internet]. 2014 [cited 2017 Apr 12];7(2):47-51. Available at: http://revistasoched.cl/2_2014/2.pdf

15. Pérez-Rodríguez $M C$, Godoy $S$, Mazzo $A$, Nogueira PC, Trevizan MA, Mendes IAC. Cuidado en los pies diabéticos antes y después de intervención educativa. Enfermería Global [Internet]. 2013 [cited 2017 May 10];12(29):4352. Available at: http://scielo.isciii.es/scielo.php?script=sci_artt ext\&pid=S1695-61412013000100003

16. Wilkinson A, Whitehead L, Ritchie L. Factors influencing the ability to self-manage diabetes for adults living with type 1 or 2 . International Journal of Nursing Studies. 2014 Jan;51(1):111122. Doi: 10.1016/j.ijnurstu.2013.01.006

17. Ramírez-Ordoñez MM, Ascanio-Carvajalino $M$, Coronado-Cote M, Gómez-Mora CA, Mayorga-
Ayala LD, Medina-Ospino R. Estilo de vida actual de los pacientes con diabetes mellitus tipo 2 . Ciencia y Cuidado. 2011;8(1):21-28. Available at:

https://dialnet.unirioja.es/descarga/articulo/38 53505.pdf Doi: http://dx.doi.org/10.22463/17949831.466

18. Baca-Martínez B, Bastidas Loaíza M de J, Aguillar $M$ del R, De La Cruz-Navarro M, GonzálezDelgado MD, Uriarte-Ontiveros $S$, et al. Nivel de conocimientos del Diabético sobre su autocuidado. Enfermería Global [Internet]. 2008 [cited 2017 Jan 28];7(13):1-13. Available at: http://revistas.um.es/eglobal/article/view/146 91

19. Herrera-Lian A, Andrade YR, Hernández SO, Manrrique JP, FAria KL, Machado M. Personas con diabetes mellitus tipo 2 y su capacidad de agencia de autocuidado, Cartagena. Av enferm [Internet]. 2012 [cited 2017 Feb 28];30(2):3946. Available at: http://www.scielo.org.co/pdf/aven/v30n2/v30 n2a03.pdf

20. Nam S, Chesla C, Stotts NA, Kroon L, Janson S. Barriers to diabetes management: Patient and provider factors. Diabetes Research and clinical practice. 2011 Jul;93(1):1-9. Doi: 10.1016/j.diabres.2011.02.002

21. López-Ramón C, Ávalos-García MI. Diabetes Mellitus tipo 2: barreras y perspectivas en el control del paciente. Horizonte sanitario. 2013 Jul;12(2):63-69. Available at https://www.redalyc.org/html/4578/45784514 4003/

22. Alves-Pereira D, Da Silva-Campos-Costa NM, Lima-Sousa AL, Brandão-Veiga-Jardim PC, De Oliveira-Zanini CR. Efectos de intervención educativa sobre el conocimiento de la enfermedad en pacientes con diabetes mellitus. Rev Latino-Am Enfermagem [Internet]. 2012 [cited 2017 Mar 10];20(3):1-8. Available at: http://www.scielo.br/pdf/rlae/v20n3/es_a08v2 On3.pdf 
23. González-Sara SH, Moreno-Pérez NE. Instrumentos para la enseñanza del proceso enfermero en la práctica línica docente con enfoque de autocuidado Nanda-Nic-Noc. Enfermería Global. 2011 Jul;10(23):89-95. Doi: http://dx.doi.org/10.4321/S169561412011000300007

24. Alvear-Galindo MG. Una propuesta para el manejo de la diabetes mellitus tipo 2 en unidades del primer nivel de atención. Fac Nac Salud Pública [Internet]. 2013 [cited 2017 Mar 20];31(1):85-92. Available at: http://www.scielo.org.co/pdf/rfnsp/v31n1/v31 n1a10.pdf

25. Hillege S, Beale S, McMaster R. Enhancing Management of Depression and Type 1 Diabetes in Adolescents and Young Adults. Archives of Psychiatric Nursing. 2011 Dec;25(6):57-67. Doi: 10.1016/j.apnu.2011.08.003

26. Melguizo-Herrera E, Alzate-Posada ML. Creencias y prácticas de cuidado de la salud de ancianos. Avances en Enfermería. 2010 Aug;(28):61-72. Available at: https://revistas.unal.edu.co/index.php/avenfer $\mathrm{m} /$ article/view/21450/22445

27. Briñez-Ariza KJ, Muñoz-de Rodríguez L. Experiencias de cuidado cultural en personas con diabetes y el contexto familiar, con enfoque de Leininger. Cultura de los Cuidados. 2016 May;20(45):81-89.

Doi: 10.14198/cuid.2016.45.09

28. Tarrés-Chamorro S. El cuidado del 'otro'. Diversidad cultural y enfermería transcultural. Gazeta de Antropología [Internet]. 2001 [cited 2017 May 11];17(15):1-6. Available at: http://www.ugr.es/ pwlac/G17_15Sol_Tarres_ Chamorro.pdf

29. Olcese-Zulueta C, Frutops-Martín M. Modelo Transcultural de los cuidados Enfermeros: hacia el cuidado integral, individualizado y universal [dissertation]. Universidad de Valladolid España; $2015 . \quad$ Available at: https://uvadoc.uva.es/bitstream/10324/11869 /1/TFG-H248.pdf
30. Linmans JJ, Van Rossem C, Knottnerus JA, Spigt $M$. Exploring the process when developing a lifestyle intervention in primary care for type 2 diabetes: a longitudinal process evaluation. Public Health. 2015 Jan;129(1):52-59. Doi: 10.1016/j.puhe.2014.11.004

31. Köster I, Huppertz E, Hauner H, Schubert I. Costs of Diabetes Mellitus (CoDiM) in Germany, direct per-capita costs of managing hyperglycaemia and diabetes complications in 2010 compared to 2001. Exp Clin Endocrinol Diabetes [Internet]. 2014 [cited 2017 Aug 9];122(9):510-516. Doi: 10.1055/s-0034-1375675

32. Ilunga Tshiswaka D, Ibe-Lamberts KD, Mulunda DM, Iwelunmor J. Perceptions of Dietary Habits and Risk for Type 2 Diabetes among Congolese Immigrants. Journal of Diabetes Research [Internet]. 2017 [cited 2018 Mar 10];2017(2017):8. Doi: https://doi.org/10.1155/2017/4736176

33. López-Ramón C, Ávalos-García MI. Diabetes mellitus hacia una perspectiva social. Revista Cubana de Salud Pública [Internet]. 2013 [cited 2017 Mar 17];39(2):331-345. Available at: http://scielo.sld.cu/scielo.php?script=sci_arttex t\&pid=S0864-34662013000200013\&lng=es.

34. Zavala M del R, Vázquez Maartínez O, Whetsell MV. Bienestar espiritual y ansiedad en pacientes diabéticos. Aquichan [Internet]. 2006 [cited 2017 Aug 17];6(1):8-21. Available at: http://aquichan.unisabana.edu.co/index.php/a quichan/article/view/76/157

35. Alvirde-Vera R, García-Reza C, Carpio- Rodríguez MA. Influencia de patrones culturales en la adhesión al tratamiento de la Diabetes [Internet]. 2009 [cited 2017 Oct 10];1-11. Available at: http://web.uaemex.mx/revistahorizontes/docs /revistas/Vol2/INFLUENCIA_DE_PATRONES_CU LTURALES.pdf

36. Amoah VMK, Anokye R, Acheampong E, Dadson $H R$, Osei $M$, Nadutey $A$. The experiences of people with diabetes-related lower limb amputation at the Komfo Anokye Teaching Hospital (KATH) in Ghana. BMC Res Notes [Internet] 2018 [cited 2018 Mar 11];11(1):66. Doi: 10.1186/s13104-018-3176-1 
37. Lopez-Amador KH, Ocampo-Barrio P. Creencias sobre su enfermedad, hábitos de alimentación, actividad física y tratamiento en un grupo de diabéticos mexicanos. Archivos en Medicina Familiar [Internet]. 2007 [cited 2017 Oct 15];9(2):80-86. Available at: http://www.medigraphic.com/pdfs/medfam/a mf-2007/amf072c.pdf

38. Molina A, Acevedo O, Yáñez ME, Dávila R, Gonzáles A. Comparación de las prevalencias de duelo, depresión y calidad de vida asociados con la enfermedad entre pacientes con diabetes mellitus tipo 2 descontrolados y controlados. Revista de Especialidades Médico-Quirúrgicas [Internet]. 2013 [cited 2017 Apr 23];18(1):1318. Available at: http://www.redalyc.org/articulo.oa?id=473263 33003

39. Del Castillo-Arevalo $F$, Salido-González $M$, Losada-García A, García-García M, FernándezPrieto T, Blanco-Gutiérrez ML. Valoración de la adherencia en el seguimiento del paciente diabético y uso del lenguaje enfermero. Enfermería Global. 2013 Apr;12(2):18-27. Doi: http://dx.doi.org/10.6018/eglobal.12.2.156481

40. Campo-Guinea N, Portillo MC. El automanejo de los pacientes con diabetes tipo 2: una revisión narrativa. An. Sist Sanit Navar [Internet]. 2013 [cited 2017 May 2];36(3):489-504. Available at: http://scielo.isciii.es/pdf/asisna/v36n3/14_revi siones.pdf

41. Galindo-Martínez MG, Rico-Herrera L, PadillaRaygoza N. Efecto de los factores socioculturales en la capacidad de autocuidado del paciente hospitalizado con diabetes tipo 2. Aquichan [Internet]. 2014 [cited 2017 Jun 21];14(1):7-19. Available at:http://www.redalyc.org/articulo.oa?id=7413 0041002

42. Ibeneme S, Eni G, Ezuma A, Fortwengel G. Roads to Health in Developing Countries: Understanding the Intersection of Culture and Healing. Current Therapeutic Research, Clinical and Experimental [Internet]. 2017 [cited 2018 Mar 10];(86):13-18. Doi: http://doi.org/10.1016/j.curtheres.2017.03.001
43. Cruz-Bello $P$, Vizcarra-Bordi I, Kaufer-Horwitz $M$, Benítez-Arciniega AD, Misra R, Valdés-Ramos R. Género y autocuidado de la diabetes mellitus tipo 2 en el Estado de México. Papeles de Población [Internet]. 2014 [cited 2017 Jan15];20(80):119-144. Available at: http://www.scielo.org.mx/pdf/pp/v20n80/v20 n80a5.pdf

44. Russo V, Avellaneda M. Hábitos alimentarios en pacientes diabéticos tipo 2 adultos que acudieron a las consultas de cardiología y clínica en el hospital provincial de la ciudad de Arroyo seco [dissertation]. Universidad Abierta Interamericana; 2011. Available at http://imgbiblio.vaneduc.edu.ar/fulltext/files/T C111568.pdf

45. Hoyos-Duque TN, Arteaga-Henao MV, MuñozCardona M. Factores de no adherencia al tratamiento en personas con Diabetes Mellitus tipo 2 en el domicilio. La visión del cuidador familiar. Investigación y Educación en Enfermería [Internet]. 2011 [cited 2017 Feb 16];29(2):194-203. Available at: http://www.redalyc.org/articulo.oa?id=105222 400005

46. Bail-Pupko V, Susana-Celeste A. Creencias y Narrativa en la Diabetes Tipo 2. VII Congreso Internacional de Investigación y Práctica Profesional en Psicología XXII Jornadas de Investigación XI Encuentro de Investigadores en Psicología del MERCOSUR. Universidad de Buenos Aires; 2015. Available at: http://www.aacademica.org/000-015/280.pdf

47. Shilubane H, Netshikweta L, Ralineba T. Beliefs and practices of diabetic patients in Vhembe district of Limpopo Province. African Journal of Primary Health Care \& Family Medicine [Internet]. 2016 [cited 2018 Mar 3];8(2)1-6. Doi: 10.4102/phcfm.v8i2.949

48. Urzua A, Chirino A, Valladares G. Autoreporte de la calidad de vida relacionada con la salud en diabetes mellitus tipo 2. Rev Med Chile. 2011 Mar;139(3):313-320. Doi: http://dx.doi.org/10.4067/S003498872011000300005 
49. Fitzpatrick S, Schumann KP, Hill-Briggs F. Problem solving interventions for diabetes selfmanagement and control: A systematic review of the literature. Diabetes Research and Clinical Practice. 2013 May;100(2):145-161. Doi: 10.1016/j.diabres.2012.12.016

50. Besher G. Testing a conceptual framework for self-care in persons with diabetes: The effect of depression [dissertation]. University of Kansas; 2012.

51. Pérez del Ángel AG. El impacto en la dinámica familiar del paciente con Diabetes Mellitus II que presenta amputación en extremidad inferior [dissertation]. Universidad Veracruz; 2015.

52. Rodriguez-Perez $M$, Alonso-Crespo FE, Hernandez SA, Vallares Hernandez O. Hábitos de consumo de alimentos de un grupo de pacientes diabéticos del municipio de Santa Clara. Universidad Ciencias Médicas; 2011-2012.

53. Stolt $M$, Suhonen $R$, Puukka $P$, Viitanen $M$, Päivi $\mathrm{V}$, Leino-Kilpi H. Nurses' foot care activities in home health care. Geriatric Nursing. 2013 Dec;34(6):491-497. Doi: https://doi.org/10.1016/j.gerinurse.2013.08.00 3

54. Gallardo-Pérez U de J, Zangronis-Ruano L, Chirino-Carreño N, Mendoza-Vélez L. Conocimientos y conductas de los pacientes con diabetes mellitus sobre el pie diabético. Rev Cubana Med Gen Integr [Internet]. 2008 [cited 2017 Oct 10];24(1):1-6. Available at: http://scielo.sld.cu/scielo.php?script=sci_arttex t\&pid=S0864-21252008000100007\&lng=es.

55. Briñez-Ariza KJ, Muñoz-de Rodríguez L. Cuidado cultural del diabético Amputado. Cultura del Cuidado [Internet]. 2013 [cited 2017 Nov 11];10(2):20-34. Available at https://www.researchgate.net/publication/266 369216_Cuidado_cultural_del_diabetico_ampu tado

56. Santana-da Silva LW, Souza-Silva J, RossiSquarcini CF, Galvão-Souza F, Do santos- Ribeiro V, Ferreira-Gonçalves D. Promoção da saúde de pessoas com diabetes mellitus no cuidado educativo preventivo do pé-diabético. Ciencia y
Emfermería [Internet]. 2016 [cited 2018 Feb 18];22(2):103-116. Available at: https://scielo.conicyt.cl/pdf/cienf/v22n2/art_0 8.pdf

57. De Almeida SA, Moura-Silveira M, Ferreira-do Espírito Santo P, De Cássia- Pereira R, MagelaSalomé G. Avaliação da qualidade de vida em pacientes com diabetes mellitus e pé ulcerado. Rev Bras Cir Plást. 2013 Jan/Mar;28(1):142146. Doi: http://dx.doi.org/10.1590/S198351752013000100024

58. Adarmouch L, Elyacoubi A, Dahmash L, El Ansari $N$, Sebbani $M$, Amine $M$. Short-term effectiveness of a culturally tailored educational intervention on foot self-care among type 2 diabetes patients in Morocco. Journal of Clinical and Translational Endocrinology. 2017 Mar;(7):54-59. Doi: 10.1016/j.jcte.2017.01.002

59. Vedhara K, Dawe K, Wetherell MA, Miles JN, Cullum N, Dayan C, et al. Illness beliefs predict self-care behaviours in patients with diabetic foot ulcers: A prospective study. Diabetes Research and Clinical Practice. 2014 Oct;106(1):67-72. Doi: 10.1016/j.diabres.2014.07.018

60. Rerkasem K. Seminar review: sociocultural practices and epidemiology of diabetic foot problem: lessons from a study in Chiang Mai University Hospital, Thailand. Int J Low Extrem Wounds. 2011 May;10(2):86-90. Doi: 10.1177/1534734611406102

61. Willrich-Böell JE, Guereiro-Vieira da Silva DM, Hegadoren KM. Sociodemographic factors and health conditions associated with the resilience of people with chronic diseases: a cross sectional study. Rev Latino-Am Enfermagem. 2016 Sep;(24). Doi: http://dx.doi.org/10.1590/15188345.1205.2786

62. Carthron D, Bailey D, Anderson R. The "invisible caregiver": multicaregiving among diabetic African-American grandmothers. Geriatric Nursing. 2014 Mar-Apr;35(2):32-36. Doi: 10.1016/j.gerinurse.2014.02.013

63. Rivera-Ledesma A, Montero-López-Lena $M$, Sandoval-Ávila R. Desajuste psicológico, calidad 
de vida y afrontamiento en pacientes diabéticos con insuficiencia renal crónica en diálisis peritoneal. Salud Mental [Internet]. 2012 [cited 2017 Sep 18];35(4):329-337. Available at http://www.scielo.org.mx/scielo.php?script=sci _arttext\&pid=S0185$33252012000400008 \& \operatorname{lng}=\mathrm{es}$.

64. Gómez-Palencia IP, Durán De Villalobos MM. Espiritualidad e incertidumbre ante la enfermedad: adultos diabéticos tip 2. Av Enferm [Internet]. 2012 [cited 2017 Oct 10]; 30(3):1828. Doi: 10.15446/av.enferm

65. Latter S, Sibley A, Skinner TC, Cradock S, Zinken $\mathrm{KM}$, Lustier MT, et al. The impact of an intervention for nurse prescribers on consultations to promote patient medicinetaking in diabetes: A mixed methods study. International Journal of Nursing Studies. 2010 Sep;47(9):1126-1138.

Doi: 10.1016/j.ijnurstu.2010.02.004

66. Torres-Leal I. Perspectiva espiritual de hombre y mujeres con Diabetes Mellitus [dissertation]. Universidad de la Sabana; 2011.

67. Calderon-Solis JM. Creencias irracionales en pacientes con diabetes Mellitus tipo 2 entre 40 y 50 años [dissertation]. Universidad Rafael Landivar; 2015.
68. Guelfucci F, Clay E, Aballéa S, Lasalle R, Moore $\mathrm{N}$, Toumi M. Impact of therapy escalation on ambulatory care costs among patients with type diabetes in France. BMC Endocr Disord [Internet]. 2013 [cited 2017 Aug 12];13(15). Doi:10.1186/1472-6823-13-15

69. Fernández AR, Manrique-Abril FG. Agencia de autocuidado y factores básicos condicionantes en adultos mayores. Av Enferm [Internet]. 2011 [cited 2017 Aug 15];29(1):30-41. Available at: http://revistas.unal.edu.co/index.php/avenfer m/article/view/35846/37059

70. Robles-González AL, López-González JA, Morales-Contreras KP, Palomino-Salazar FL, Figueroa-Betancourt YD. Autocuidado y Factores Condicionantes Presentes en las Personas con Diabetes Tipo 2 de una Colonia de Hermosillo, Sonora. Unison / Epistemus [Internet]. 2014 [cited 2017 Aug 15];(17):41-49. Available at: http://www.epistemus.uson.mx/revistas/articu Ios/17-6PERSONAS_CON_DIABETESTIPO2.pdf

71. Álvarez-Zúñiga LA. Creencias irracionales y su influencia en la calidad de vida de pacientes con diabetes mellitus tipo 2 [Internet]. Repositorio Digital. Universidad Técnica de Ambato; 2018. Available at: http://repositorio.uta.edu.ec/jspui/handle/123 $456789 / 24004$ 